\title{
Competency-based SBIRT training for health-care professionals: nursing and social work students
}

\author{
Heather J Gotham*, Sarah Knopf-Amelung, Laurie Krom, Pat Stilen, Kendall Kohnle \\ From 2014 Addiction Health Services Research (AHSR) Conference \\ Boston, MA, USA. 15-17 October 2014
}

\section{Background}

Most health-care professional training programs lack educational curricula on substance use disorders and strategies for early intervention or referral to treatment. The University of Missouri-Kansas City Screening, Brief Intervention and Referral to Treatment (UMKC-SBIRT) training project educates baccalaureate nursing, advanced practice nursing, and master's of social work students through didactics threaded throughout coursework; roleplays with classmates and faculty; standardizes patient practice; and offers clinical experience to help students achieve competency.

\section{Methods}

In year one of the training grant, students completed surveys prior to, immediately after, and 30 days after SBIRT training. Surveys covered attitudes and knowledge. Skills were assessed by expert coding of an audiotaped interaction with a standardized patient actor using an SBIRT fidelity scale. Qualitative feedback regarding training experience, knowledge, and attitudes was collected at post-training focus groups.

\section{Results}

Students showed increased knowledge of SBIRT, improved perceptions toward working with patients who use substances, increased comfort in dealing with substance use issues, and progress in developing skills to provide SBIRT interventions.

\section{Conclusions}

Training on SBIRT can be readily implemented into nursing and social work education, improving future health

\footnotetext{
* Correspondence: gothamhj@umkc.edu

School of Nursing and Health Studies, University of Missouri-Kansas City,
} Kansas City, MO, 64108, USA
Submit your next manuscript to BioMed Central and take full advantage of:

- Convenient online submission

- Thorough peer review

- No space constraints or color figure charges

- Immediate publication on acceptance

- Inclusion in PubMed, CAS, Scopus and Google Scholar

- Research which is freely available for redistribution 